$\mathrm{DE}$

M E D I C I N A

T R O P I C A L

$\mathrm{DE}$

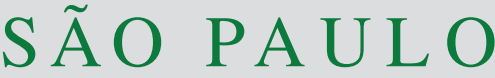

JOURNAL OF THE SÃO PAULO INSTITUTE OF TROPICAL MEDICINE

1 Universidad Nacional Autónoma de México (UNAM), Facultad de Medicina, Departamento de Microbiología y Parasitología, Ciudad de México, México

${ }^{2}$ Hospital Regional de Alta Especialidad de Ixtapaluca, Ixtapaluca, México

${ }^{3}$ Hospital General de México, Ciudad de México, México

Correspondence to: Rafael GarcíaGonzález

Universidad Nacional Autónoma de México (UNAM), Facultad de Medicina, Departamento de Microbiología y Parasitología, Avenida Universidad, №3000, 04510, Cd.Mx., México

E-mail: rafagargon@ hotmail.com

Received: 12 November 2018

Accepted: 18 March 2019

\section{Genotyping of Leptospira interrogans isolates from Mexican patients}

\author{
Rafael García-González ${ }^{\circledR 1}$, Angélica Reyes-Torres ${ }^{1}$, María del Rocío \\ Reyes-Montes ${ }^{\left({ }^{1} 1\right.}$, Esperanza Duarte-Escalante ${ }^{\left({ }^{1} 1\right.}$, María Guadalupe \\ Frías-De-León ${ }^{\circledR 2}$, Beatriz Rivas-Sánchez ${ }^{3}$, Oscar Velasco-Castrejón ${ }^{3}$
}

\section{ABSTRACT}

The aim of this study was genotypically characterize Leptospira sp. clinical isolates from Mexico which were previously identified as Leptospira interrogans serovar Pomona (POM) by phenotypic methods. The Random Amplified Polymorphic DNA (RAPD) method was used for DNA amplification with five oligonucleotides. A dendrogram was constructed using the Unweighted Pair Group Method Analysis (UPGMA). During the genotypic characterization, the studied isolates constituted a group which was associated with the reference strain L. interrogans serovar Pomona. The Minimum Spanning Networks (MST) analysis revealed the same cluster between Mexican isolates and the reference strain POM. Clinical isolates identified as $L$. interrogans serovar POM have a clonal reproduction type, suggesting that this clone is distributed in different regions of Mexico.

KEYWORDS: L. interrogans serovar POM. RAPD. UPGMA. Minimum Spanning Networks.

\section{INTRODUCTION}

Leptospirosis is caused by spirochetes that belong to the genus Leptospira, phylum Spirochaetes, order Spirochaetales and family Leptospiraceae ${ }^{1}$. Leptospirosis is a zoonosis of broad global distribution and is common in tropical and subtropical areas, although it is not rare in temperate zones ${ }^{2}$. Leptospirosis is transmitted to humans by contaminated mud and/or water or by direct contact with the urine of infected animals ${ }^{1}$. Cases of transmission from humans to animals have also been reported ${ }^{3}$.

According to data reported by the World Health Organization (WHO), more than 500,000 cases of severe leptospirosis occur each year, with lethality rates higher than $10 \%$. However, the burden of the disease is significantly underestimated due to limited epidemiological data and to the low sensitivity of standard diagnostic tests (culture and the microscopic agglutination test), which makes the diagnosis difficult ${ }^{4}$. In Mexico, according to the General Directorate of Epidemiology, the epidemiology of leptospirosis revealed a national rate of 0.65 cases per 100,000 inhabitants by the year 2000, and 45 by 2010, being stable over the last 10 years, according to the Handbook of standardized procedures for the epidemiological surveillance of leptospirosis 5 .

The traditional taxonomic system, based on serology, divides the genus Leptospira into two species: Leptospira interrogans (pathogenic) and L. biflexa (non-pathogenic). These species are further divided into 26 serogroups, over 
300 serovars and strains, based on shared antigens ${ }^{4,6,7}$. Although this system has great epidemiological value, nowadays, molecular methods are needed for identifying and classifying the genus Leptospira ${ }^{8}$. The analysis based on DNA has identified 22 Leptospira species with nine main pathogenic species (L. interrogans, $L$. borgpetersenii, L. santarosai, L. noguchii, L. weilii, L. kirschneri, L. alexanderi, L. alstonii, and L. kmetyi) and six nonpathogenic species ${ }^{9,10}$.

Thus, the characterization of Leptospira strains has evolved to more reliable and robust modern methods, including RFLP (Restriction Fragment Length Polymorphism) ${ }^{11}$, PFGE (Pulsed-Field Gel Electrophoresis) $)^{11,12}$, REA (Restriction Enzyme Analysis) ${ }^{13}$, RAPD (Random Amplified Polymorphic DNA) ${ }^{13,14}, 16 \mathrm{~S}$ rRNA sequencing ${ }^{15}$, VNTR (Variable Number of Tandem Repeats) analysis, and MLST (Multilocus Sequence Typing), making it possible to obtain information about the molecular epidemiology of leptospirosis ${ }^{12,16-21}$. Among these techniques, RAPD has been used for identifying and typing Leptospira isolates. RAPD is a rapid, sensitive, safe and relatively simple technique; furthermore, the products obtained can be used in studies of phylogeny and population structure $8,14,18,19,22-24$. There are few genotypic characterization studies of Leptospira clinical isolates in Mexico (MX); therefore, some aspects of epidemiological importance remain unknown, such as the distribution of circulating clones in different regions of the country which could allow the understanding of the pathogen's transmission dynamics and hence, the implementation of adequate prevention and control measures. The aim of this study was to genotype clinical isolates of Leptospira sp. obtained from Mexican patients, using the RAPD method.

\section{MATERIAL AND METHODS}

\section{Reference strains}

Eleven reference strains (Table 1) were used. Strains were maintained in Ellinghausen and McCullough liquid culture medium modified by Johnson and Harris (EMJH) (Difco Laboratories, Detroit, USA) supplemented with SAVAT (Tween 80-bovine serum albumin, Difco Laboratories, Detroit, USA), at $28-30{ }^{\circ} \mathrm{C}$.

\section{Clinical isolates}

In total, 89 primary cultures of Leptospira sp. obtained from Mexican patients with diagnosis of chronic leptospirosis were used. The isolates were phenotypically identified as $L$. interrogans serovar Pomona ${ }^{25}$. These
Table 1 - Reference strains of Leptospira interrogans, corresponding species and serovar.

\begin{tabular}{lcc}
\hline $\begin{array}{l}\text { Reference } \\
\text { strains }\end{array}$ & \multicolumn{1}{c}{ Species } & Serovar \\
\hline ICT & Leptospira interrogans & Icterohaemorrhagiae \\
CAN & Leptospira interrogans & Canicola \\
POM & Leptospira interrogans & Pomona \\
AUT & Leptospira interrogans & Autumnalis \\
BRA & Leptospira interrogans & Bratislava \\
TA & Leptospira interrogans & Tarassoni \\
LAI & Leptospira interrogans & Icterohaemorrhagiae \\
& & lai lai \\
PYR & Leptospira interrogans & Pyrogenes \\
BAL & Leptospira interrogans & Balum \\
SHER & Leptospira interrogans & Shermani \\
PTC & Leptospira interrogans & Ptc Patoc \\
\hline
\end{tabular}

primary cultures were sub-cultured in $3 \mathrm{~mL}$ of EMJH liquid culture medium (Difco), supplemented with SAVAT and de-complemented rabbit serum ${ }^{3}$. A 1:10 dilution of sample-culture medium was used and then incubated at 28-30 ${ }^{\circ} \mathrm{C}$; samples were checked weekly, over six months, under a dark field microscope to ensure the development and adaptation to the culture medium ${ }^{3,26,27}$. The morphological study of Leptospira sp. was performed by a video recording apparatus using dark field microscopy (Carl Zeiss, Jena, Germany), with an immersion dark field condenser, at 400X magnification, connected to a high resolution video camera (Samsung, South Korea) and a screen (Sony, Japan) ${ }^{3,28}$.

\section{Extraction of genomic DNA}

The isolates and reference strains were cultured in $50 \mathrm{~mL}$ of EMJH for 7-10 days and centrifuged at $5600 \mathrm{~g}$ for 20 min at $4{ }^{\circ} \mathrm{C}$, discarding the supernatant. Subsequently, the pellet was washed with TE buffer $(10 \mathrm{mM}$ Tris-HCl $\mathrm{pH}$ 8.0, $1 \mathrm{mM}$ EDTA). Immediately thereafter, cellular packages were heated at $80{ }^{\circ} \mathrm{C}$ for $10 \mathrm{~min}$ to inactivate cells; the recovered material was placed in $1.5-\mathrm{mL}$ vials, resuspended in $200 \mu \mathrm{L}$ of isotonic saline solution, and centrifuged at $10000 \mathrm{~g}$ for $5 \mathrm{~min}$. The FastDNA ${ }^{\circledR}$ SPIN Kit (Qiagen GmbH, Hilden, Germany) was used according to the manufacturer's instructions for DNA extraction. DNA concentration was determined by spectrophotometry and by $1 \%$ ethidium bromide-stained agarose gel electrophoresis $(10 \mu \mathrm{g} / \mathrm{mL})$ (Sigma-Aldrich, St. Louis, Missouri, USA). Different concentrations of $\lambda$ phage (Invitrogen, Carlsbad, California, USA) were used as a reference. The isolated DNA was stored at $4{ }^{\circ} \mathrm{C}$. 
RAPD

For these assays, the O5 (5'-AGGGGTCTTG-3') oligonucleotide ${ }^{19}$, the combination of $\mathrm{B} 11$ ( 5' - CCGGAAGAAGGGGCGCCAT-3') and B 12 (5'-CGATTTAGAAGGACTTGCACAC-3') oligonucleotides $^{24}$, the M16 (5'-AAAGAAGGACTCA GCGACTGCG-3') oligonucleotide ${ }^{14}$, and the PB1 (5'-GCGCTGGCTCAG-3') oligonucleotide ${ }^{14}$ were used as described in Table 2.

\section{Data analysis}

RAPD resulting bands on different gels were statistically analyzed. RAPD markers were visually recorded, manually coded and translated into binary data that indicated either their presence (1) or absence (0). The genetic similarity between isolates was calculated with the Jaccard index. Genetic relationships among isolates were assessed using the mean of the Unweighted Pair Group Method with Arithmetic Mean (UPGMA). Distortion of the inferred tree was assessed with the cophenetic correlation coefficient $(\mathrm{CCCr})$, which was calculated using the Mantel test ${ }^{29}$. A multidimensional analysis of minimum spanning networks (MST) was performed based on the original similarity matrix. Multivariate statistical methods were carried out using the NTSYS-PC program (version 2.0,
Exeter Software, New York, USA) ${ }^{30}$. To distinguish clonal and recombinant structures in Leptospira isolates, the Index of Association $\left(I_{A}\right)$, was used, which is a statistical test that measures the degree of non-random association between alleles at different loci (linkage disequilibrium) ${ }^{31}$. Therefore, $I_{A}$ is zero in strictly recombining populations and 1 in strictly clonal populations. $I_{A}$ was calculated using the LIAN 3.5 software ${ }^{32}$.

\section{RESULTS}

\section{Clinical isolates}

Only 12 of the 87 primary isolates were adapted to the culture medium and showed characteristic spirochete morphology with one or two hooks, closed spirals, translational, helical and rotational movements, compatible with genus Leptospira (Table 3). This morphology was evident through video recording in dark field and with silver staining.

\section{Genotypic characterization}

DNA samples were obtained in a concentration range of 50 to $200 \mathrm{ng} / \mu \mathrm{L}$ and were adjusted to a concentration of $20 \mathrm{ng} / \mu \mathrm{L}$ for RAPD assays.

The number of markers obtained for each oligonucleotide

Table 2 - RAPD conditions used with each oligonucleotide.

\begin{tabular}{|c|c|c|c|c|}
\hline Oligonucleotide & 05 & B11-B12 & M16 & PB1 \\
\hline Reaction volume & $25 \mu \mathrm{L}$ & $25 \mu \mathrm{L}$ & $25 \mu \mathrm{L}$ & $25 \mu \mathrm{L}$ \\
\hline DNA & $20 \mathrm{ng}$ & $20 \mathrm{ng}$ & 20 ng & $20 \mathrm{ng}$ \\
\hline $\begin{array}{l}\text { Taq buffer } 10 \mathrm{X} \text { (Tris-HCl } \\
100 \mathrm{mM}, \mathrm{KCl} 500 \mathrm{mM} \text {, } \\
\mathrm{pH} 9.0)\end{array}$ & $1 X$ & $1 X$ & $1 X$ & $1 X$ \\
\hline dNTPs & $0.1 \mathrm{mM}$ of each & $0.1 \mathrm{mM}$ of each & $250 \mu \mathrm{M}$ of each & $250 \mu \mathrm{M}$ of each \\
\hline $\mathrm{MgCl}_{2}$ & $3.5 \mathrm{mM}$ & $4.5 \mathrm{mM}$ & $1.5 \mathrm{mM}$ & $3.5 \mathrm{mM}$ \\
\hline Oligonucleotide & $300 \mathrm{pmol}$ & $300 \mathrm{pmol}$ & 200 pmol & $300 \mathrm{pmol}$ \\
\hline Taq DNA polimerase & $0.5 \mathrm{U}$ & $0.5 \mathrm{U}$ & $0.5 \mathrm{U}$ & $0.5 \mathrm{U}$ \\
\hline Amplification program & $\begin{array}{l}\text { One initial cycle of one } \\
\text { min at } 94^{\circ} \mathrm{C} \text {, followed } \\
\text { by } 40 \text { cycles of } 1 \text { min at } \\
94^{\circ} \mathrm{C}, 1 \text { min at } 36^{\circ} \mathrm{C} \text {, } \\
\text { and } 2 \text { min at } 72^{\circ} \mathrm{C} \text {, with } \\
\text { a final extension cycle } \\
\text { of } 3 \text { min at } 72^{\circ} \mathrm{C}\end{array}$ & $\begin{array}{l}\text { Two cycles of } 5 \text { min at } \\
95^{\circ} \mathrm{C}, 5 \text { min at } 40^{\circ} \mathrm{C} \text {, } \\
\text { and } 5 \text { min at } 72^{\circ} \mathrm{C} \text {, fol- } \\
\text { lowed by } 35 \text { cycles of } \\
1 \text { min at } 95^{\circ} \mathrm{C}, 1 \text { min } \\
\text { at } 60^{\circ} \mathrm{C} \text {, and } 3 \text { min at } \\
72^{\circ} \mathrm{C} \text {, with one final ex- } \\
\text { tension cycle of } 72^{\circ} \mathrm{C} \\
\text { for } 10 \text { min }\end{array}$ & $\begin{array}{l}\text { One cycle of } 3 \text { min at } \\
94{ }^{\circ} \mathrm{C}, 1 \text { min at } 55^{\circ} \mathrm{C} \text {, } \\
\text { and } 2 \text { min at } 72{ }^{\circ} \mathrm{C} \text {, } \\
\text { followed by } 38 \text { cycles } \\
\text { of } 1 \text { min at } 94{ }^{\circ} \mathrm{C} \text {, } 1 \\
\text { min at } 55^{\circ} \mathrm{C} \text {, and } 2 \\
\text { min at } 72{ }^{\circ} \mathrm{C} \text {, with a } \\
\text { final extension cycle of } \\
1 \text { min at } 94^{\circ} \mathrm{C} \text {, } 1 \text { min } \\
\text { at } 55^{\circ} \mathrm{C} \text {, and } 9 \text { min at } \\
72{ }^{\circ} \mathrm{C}\end{array}$ & $\begin{array}{l}\text { One cycle of } 7 \text { min at } \\
94{ }^{\circ} \mathrm{C}, 1 \text { min at } 40^{\circ} \mathrm{C} \text {, } \\
\text { and } 1 \text { min at } 72^{\circ} \mathrm{C} \text {, and } \\
\text { four cycles of } 1 \text { min at } \\
94{ }^{\circ} \mathrm{C}, 1 \text { min at } 40^{\circ} \mathrm{C} \text {, } \\
\text { and } 1 \text { min at } 72{ }^{\circ} \mathrm{C} \text {, } \\
\text { which continued with } \\
24 \text { cycles of } 1 \text { min at } \\
94{ }^{\circ} \mathrm{C}, 1 \text { min at } 55^{\circ} \mathrm{C} \text {, } \\
\text { and } 1 \text { min at } 72^{\circ} \mathrm{C} \text {, with } \\
\text { a final extension cycle } \\
\text { of } 1 \text { min at } 94^{\circ} \mathrm{C}, 1 \text { min } \\
\text { at } 55^{\circ} \mathrm{C} \text {, and } 7 \text { min at } \\
72{ }^{\circ} \mathrm{C}\end{array}$ \\
\hline
\end{tabular}


Table 3 - Leptospira isolates obtained from Mexican patients.

\begin{tabular}{cc}
\hline Isolate & Abbrevation \\
\hline Rivepal & RIV \\
Verimol & SM \\
Veriluma & LMJT \\
Verimer & GGMC \\
Beribéri & BRS \\
Rivemar & LMFA \\
Verimat & MGR \\
Beriveca & BCB \\
Vecorisa & VECO \\
Verijua & HCHJ \\
Verichan & CHAN \\
Veritsa & TSAB \\
\hline
\end{tabular}

was 26 for the $\mathrm{O} 5$ oligonucleotide, 40 for the combination of B11-B12 oligonucleotides, 21 for the M16 oligonucleotide and 13 for the PB1 oligonucleotide, yielding 100 markers in total. Furthermore, the isolates from MX showed an identical band pattern, while reference strains corresponding to different serovars displayed different polymorphic patterns, as shown with the B11-B12 oligonucleotides (Figure 1).
The dendrogram constructed by UPGMA, based on the matrix of the presence and absence of bands with the 100 markers obtained by RAPD, showed six groups (Figure 2). Group I included three reference isolates (ICT, PYR, and CAM), with a similarity percentage among them of $48 \%$. Group II included two reference strains (BALL and SHER), with a similarity percentage of 64\%. Group III grouped all isolates of MX (RIV, SM, LMJT, TSAB, CHAN, HCHJ, VECO, BCB, MGR, MMFA, BRS, and GGMS), with a similarity percentage among them of $100 \%$ and a bootstrap of $100 \%$; this group was associated with the reference strain POM at $80 \%$. Group IV included the reference isolate PTC, with $28 \%$ similarity with the other groups. Group V included two reference isolates (AUT and TA) and was associated with the rest of the isolates at $22 \%$. Finally, Group VI was composed of two reference strains (BRA and LAI), with $20 \%$ similarity with the rest of isolates. The cophenetic correlation coefficient $(\mathrm{CCCr}=0.99$, $P<0.0004$ ) showed that the tree was a good representation of the genetic relationship of the isolates and that different groups were consistent.

The multidimensional analysis with MST revealed the same grouping between the isolates from MX and the reference strains POM. The MST analysis showed a direct relationship between the MX isolates and the reference strain
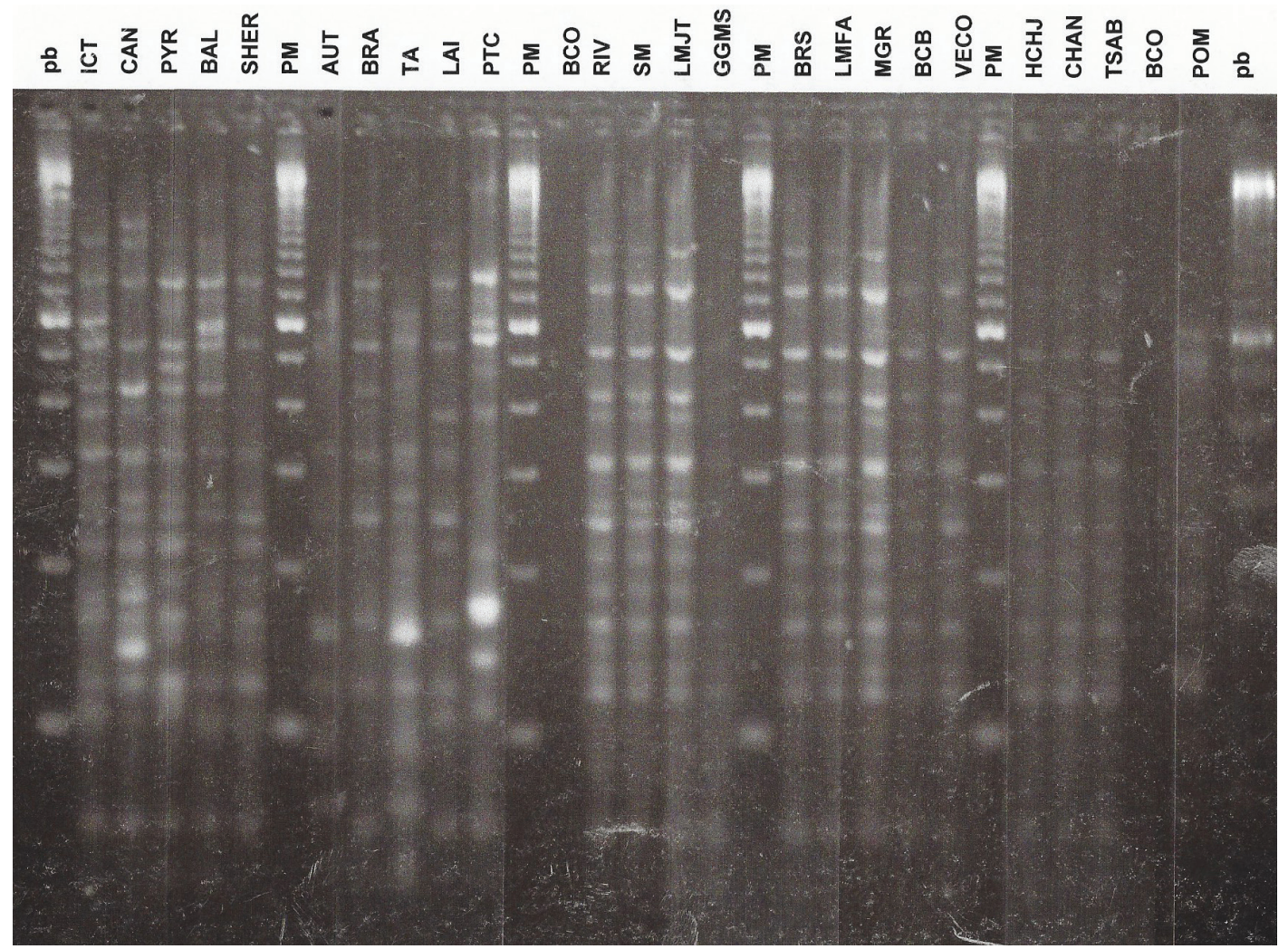

Figure 1 - Polymorphic patterns from the Mexican isolates and the reference strains obtained by RAPD using a combination of B11-B12 oligonucleotides. 


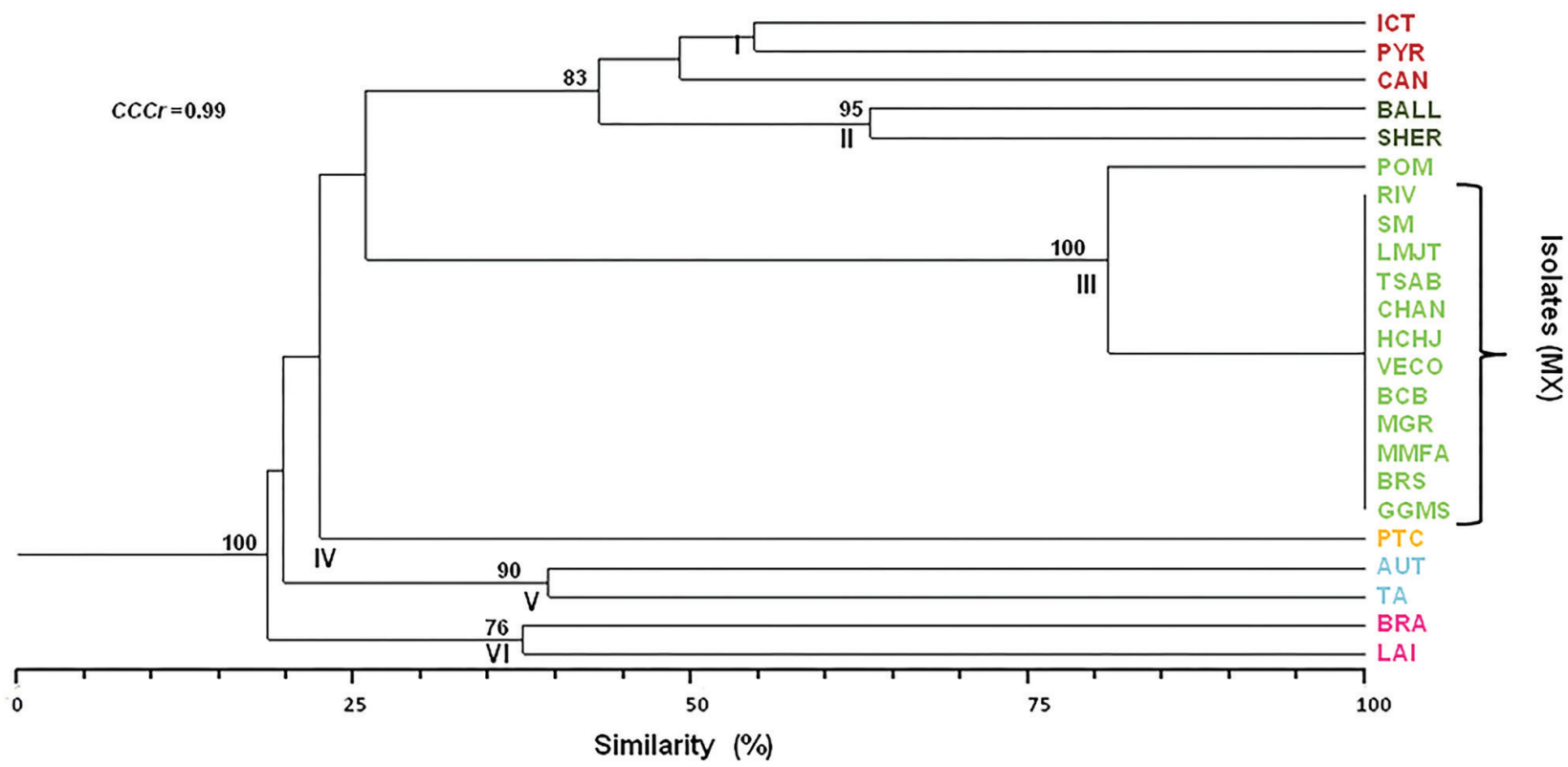

Figure 2 - Phenogram of Leptospira isolates obtained by RAPD. The phenogram was generated from genetic similarity coefficients obtained by determining the presence and absence of 100 DNA fragments from 12 Mexican Leptospira isolates and 11 reference strains, and is based on UPGMA. The numbers below the branches represent indices of support based on 1,000 bootstrap replications. Group I; Group II; Group III; Group IV; Group V; Group VI.

POM of L. interrogans serovar Pomona (Figure 3). A similar grouping was obtained in the dendrogram constructed with the oligonucleotides B11-B12 (Supplemental Figure).
The $I_{A}$ value for the group of L. interrogans serovar Pomona isolated from MX was $1.0002(P<0.001)$, which confirmed that they exhibited clonal reproduction.

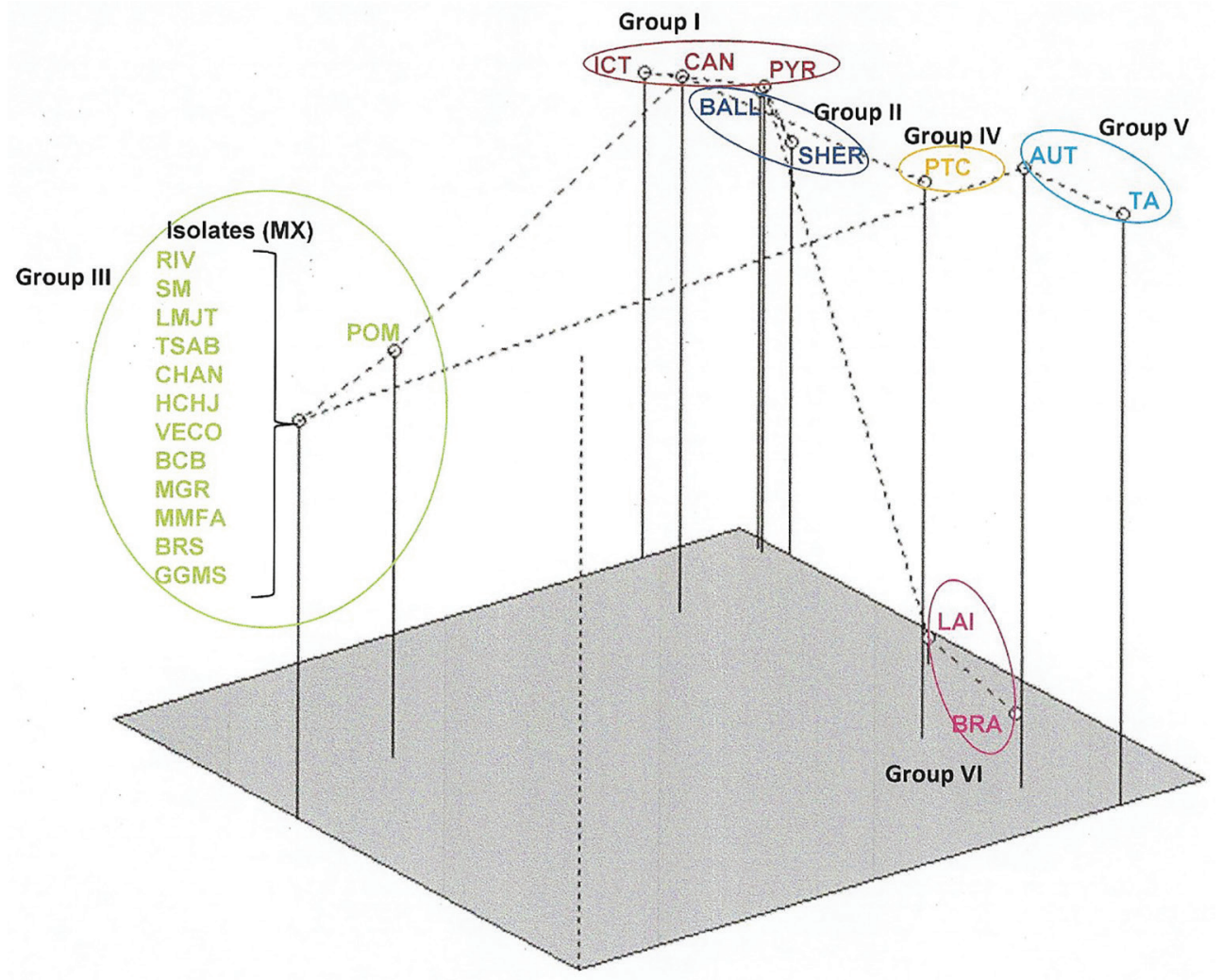

Figure 3 - Minimum spanning network (MST) of Leptospira isolates. All Mexican isolates form one group, directly related to the reference strain POM (L. interrogans serovar Pomona). Group I; Group II; Group III; Group IV; Group V; Group VI. 


\section{DISCUSSION}

Infectious diseases cause approximately one-third of all deaths worldwide, in both children and adults. Earlier in this century, infectious diseases caused 5.7 million deaths, half of them in developing countries, where approximately 1,500 people died each hour. Most infectious diseases are zoonoses and among these is leptospirosis, which is considered a very important re-emerging disease in America, particularly in Latin America, with an incidence of 100 cases per 100,000 inhabitants/year during epidemics in tropical areas ${ }^{26}$.

Leptospirosis usually presents with a wide range of clinical manifestations ${ }^{33-36}$, sometimes similar to other diseases $^{33,37}$, therefore requiring the direct or indirect dentification of the causative agent ${ }^{18,37,38}$.

Traditionally, the methods used in the identification and typing of different L. interrogans serovars are based on the study of their morphological characteristics, staining, structure, metabolic products and antigenic characteristics ${ }^{25}$. These procedures are slow and laborious, as has been widely mentioned in the literature ${ }^{23,26}$. A major disadvantage of these methods is that the phenotypic characteristics can change because of the technical procedures used, mutations or genetic exchange. The phenotypic characterization, despite its disadvantages, made it possible to identify L. interrogans serovar Pomona ${ }^{25}$. However, to confirm the identity of the studied isolates, molecular markers that have been used for decades to genotype members of the genus Leptospira were used. These molecular techniques make it possible to discriminate genetic differences among organisms, making it possible to identify strains from the same serovar in different geographical areas ${ }^{16}$. In this study, the RAPD was a useful tool for genotypically classifying clinical isolates of Leptospira from MX, phenotypically identified as L. interrogans serovar Pomona ${ }^{25}$, showing a polymorphic pattern that was identical among them and different from the strains used as reference. The exception was the strain corresponding to L. interrogans serovar Pomona, which showed a similarity of $80 \%$, as presented in Figure 2, confirmed by MST. In addition, this group showed a clonal reproduction evidenced by an $I_{A}(1.0002)$ (Figure 3 ).

This work suggests the presence of $L$ interrogans serovar Pomona in clinical isolates. The hosts of this microorganism are both marine and land animals; among the latter are domestic animals, a finding that has been demonstrated in dogs from the North of Mexico City by Rivera et al.$^{39}$. Recently, it has been reported that South of Mexico $\mathrm{City}^{40}$, humans can be infected by accidental contact with contaminated ground or water or by direct contact with animals carrying the causative agent of leptospirosis ${ }^{20,41,42}$.
It has also been reported that the association of a particular serovar with an animal species acting as a carrier, is not absolute. L. interrogans serovar Pomona has previously had different types of carriers, such as horses, swine, dogs and other animals ${ }^{39-42}$. In this study, the isolates were from patients of different geographical regions in the Mexican Republic, such as Mexico City, Mexico State, Hidalgo, Veracruz and Yucatan. These are places where patients' contact with different animals and their excretions might have occurred, however, the source of infection is unknown.

\section{CONCLUSION}

The presence of L. interrogans serovar Pomona was confirmed in clinical isolates from different geographical regions of the Mexican Republic. In addition, the L. interrogans serovar Pomona strain isolated from patients has a clonal reproduction system, which means that this clone is spread throughout different Mexican regions.

\section{CONFLICTS OF INTERESTS}

The authors have declared that no competing interests exist.

\section{AUTHORS' CONTRIBUTIONS}

RGG, MRRM, designed the study, wrote and revised the manuscript. BRS and OVC performed the recruitment for the collection of clinical isolates and carried out the phenotyping identification. ART performed the RAPD-PCR assays. EDE, MRRM and MGFDL performed the bioinformatics analysis. All authors contributed to and have approved the final manuscript.

\section{ACKNOWLEDGMENTS}

This project was supported by PAPIIT-DGAPA (IN215009).

\section{REFERENCES}

1. Adler B, de la Peña Moctezuma A. Leptospira y leptospirosis. Vet Microbiol. 2010;140:287-96.

2. García-González R, Reyes-Torres A, Basilio-Hernández DH, Ramírez-Pérez M, Rivas-Sánchez B. Leptospirosis; un problema de salud pública. Rev Latinoam Patol Clin. 2013;60:57-70.

3. Velasco-Castrejón O, Rivas-Sánchez B, Sánchez-Spíndola ME, Soriano J, Rivera-Reyes HH, Garibay SV. Leptospirosis crónica en México: diagnóstico microscópico y evidencias que 
respaldan su existencia e importancia. Rev Mex Patol Clin. 2009;56:157-67.

4. Cerqueira GM, Picardeau M. A century of Leptospira strain typing. Infect Genet Evol. 2009;9:760-8.

5. México. Secretaría de Salud. Grupo Técnico Interinstitucional del Comité Nacional para la Vigilancia Epidemiológica (CoNaVE). Manual de procedimientos estandarizados para la vigilancia epidemiológica de la leptospirosis. México, DF: Secretaría de Salud; 2012.

6. Budihal SV, Perwez K. Leptospirosis diagnosis: competancy of various laboratory tests. J Clin Diagn Res. 2014;8:199-202.

7. Hartskeerl RA, Smythe LD. The role of leptospirosis reference laboratories. Curr Top Microbiol Immunol. 2015;387:273-88.

8. Levett PN. Leptospirosis. Clin Microbiol Rev. 2001;14:296-326.

9. Varni V, Ruybal P, Lauthier JJ, Tomasini N, Brihuega B, Koval A, et al. Reassessment of MLST schemes for Leptospira spp. typing worldwide. Infect Genet Evol. 2014;22:216-22.

10. Fouts DE, Matthias MA, Adhikarla H, Adler B, Amorim-Santos L, Berg DE, et al. What makes a bacterial species pathogenic? comparative genomic analysis of the genus Leptospira. PLoS Negl Trop Dis. 2016;10: e0004403.

11. Turk N, Milas Z, Mojcec V, Ruzic-Sabljic E, Staresina V, Stritof $\mathrm{Z}$, et al. Molecular analysis of Leptospira spp, isolated from humans by restriction fragment length polymorphism, real-time PCR and pulsed-field gel electrophoresis. FEMS Microbiol Lett. 2009;300:174-9.

12. Majed Z, Bellenger E, Postic D, Pourcel C, Baranton G, Picardeau M. Identification of variable-number tandem-repeat loci in Leptospira interrogans sensu stricto. J Clin Microbiol. 2005;43:539-45.

13. Gerritsen MA, Smits MA, Olyhoek T. Random amplified polymorphic DNA fingerprinting for rapid identification of leptospires of serogroups Sejroe. J Med Microbiol. 1995;42:336-39.

14. Roy S, Biswas D, Vijayachari P, Sugunan AP, Sehgal CS. A 22-mer primer enhances discriminatory power of AP-PCR fingerprinting techniques in characterization of leptospirosis. Trop Med Int Health. 2004;9:1203-9.

15. Morey RE, Galloway RL, Bragg SL, Steigerwalt AG, Mayer LW, Levett PN. Species-specific identification of Leptospiraceae by 16s RNA gene sequencing. J Clin Microbiol. 2006;44:3510-6.

16. Natarajaseenivasan K, Vijayachari P, Sharma S, Roy S, Sugunan AP, Biswas D, et al. Pylogenetic relatedness among leptospiral straits belongins to same serovar recovered from patients with different clinical syndromes. Infect Genet Evol. 2005;5:185-91.

17. Ahmed N, Devi SM, Valverde ML, Vijayachari P, Machang'u RS, Ellis WA, et al. Multilocus sequence typing method for identification and genotypic classification of pathogenic Leptospira species. Ann Clin Microbiol Antimicrob. 2006;5:28.

18. Romero EC, Yasuda PH. Molecular characterization of Leptospira spp. strain isolated from human subjects in Sao Paulo, Brazil using a polymerase chain reaction-based assay: a public health tool. Mem Inst Oswaldo Cruz. 2006;101:373-8.

19. Resch G, Awad-Masalmeh M, Bakoss P, Jareková J. Utility of phylogenetic studies in the identification of Leptospira strains. Epidemiol Infect. 2007;135:1266-73.

20. Thaipadungpanit J, Wuthiekanun V, Chierakul W, Smythe LD, Petkanchanapong W, Limpaiboon R, et al. Dominant clone of Leptospira interrogans associated with an outbreak of human leptospirosis in Thailand. PLoS Negl Trop Dis. 2007;1:e56.

21. Caimi K, Varni V, Melendez Y, Koval A, Brihuega B, Ruybal P. A combined approach of VNTR and MLST analysis: improving molecular typing of Argentinean isolates of Leptospira interrogans. Mem Inst Oswaldo Cruz. 2012;107:644-51.

22. Perolat P, Merien F, Ellis WA, Baranton G. Characterization of leptospira isolates from serovar Hardjo by ribotyping, arbitrarily primer PCR, and mapped restriction site polymorphisms. J Clin Microbiol. 1994;32:1949-57.

23. Corney BG, Colley J, Graham GC. Simplified analysis of pathogenic leptospiral serovars by random amplified polymorphic DNA fingerprinting. J Med Microbiol. 1997;46:927-32.

24. Ramadass P, Latha D, Senthilkumar A, Srinivasan P, Saranya N. Arbitrarily primed PCR: a rapid and simple method for typing of leptospiral serovars. Indian J Med Microbiol. 2002;20:25-8.

25. Rivas-Sánchez B, Velasco-Castrejón O, Jiménez-Martínez J. Isolation of $\mathrm{L}$ interrogans serovar Pomona in 14 human cases and an African Lion, all with chronic leptospirosis. Open J Med Microbiol. 2016;6:158-70.

26. World Health Organization. Leptospirosis worldwide, 1999. Wkly Epidemiol Rec. 1999;74:237-42.

27. Organización Panamericana de la Salud. Organización Mundial de la Salud. International Leptospirosis Society. Leptospirosis humana: guía para el diagnóstico, vigilancia y control. Rio de Janeiro: Centro Panamericano de Fiebre Aftosa; 2008.

28. Velasco-Castrejón O, Rivas-Sánchez B, Espinoza-Hernández J, Martínez- Hernández E. Diagnóstico de Leptospirosis crónica, comparación entre aglutinación microscópica y 3 técnicas diagnósticas confirmatorias. Rev Cubana Med Trop. 2007;59:8-13.

29. Manly BF. Randomization, bootstrap, and Monte Carlo methods in biology. $2^{\text {nd }}$ ed. London: Chapman \& Hall; 1997.

30. Rohlf FJ. NTSYS-pc: numerical taxonomy and multivariate analysis system version 2.1. New York: Exeter Software; 2000.

31. Smith JM, Smith NH, O'Rourke M, Spratt BG. How clonal are bacteria? Proc Natl Acad Sci USA. 1993;90:4384-8.

32. Haubold B, Hudson RR. LIAN 3.0: detecting linkage disequilibrium in multilocus data. Linkage analysis. Bioinformatics. 2000;16:847-8.

33. Carrada-Figueroa G, Calderón-Valencia EG, Martínez-Hernandéz CM. Leptospirosis: pleomorfismo clínico en el síndrome febril. Salud Tabasco. 2002;8:128-32. 
34. Céspedes ZM. Leptospirosis: enfermedad zoonótica reemergente. Rev Peru Med Exp Salud Publica. 2005;22:290-307.

35. Vargas-Cuba F, García-Apaico V, Céspedes M, Palomino-Enciso M, Ayala-Huaytalla T. Seroprevalencia y factores asociados con leptospirosis en pacientes con síndrome febril en Ayacucho, Perú. Rev Peru Med Exp Salud Publica. 2008;25:190-4.

36. Gasem MH, Wagenaar JF, Goris M, Adi MS, Isbandrio BB, Hartskeerl RA, et al. Murine typhus and leptospirosis as causes of acute undifferentiated fever, Indonesia. Emerg Infect Dis. 2009; $15: 975-7$

37. Dircio Montes Sergio A, González Figueroa E, Verdalet Guzmán MS, Soler Huerta E, Rivas Sánchez B, Altuzar Aguilar V, et al. Leptospirosis prevalence with initial diagnosis of dengue. J Trop Med. 2012;2012:519701.

38. Santiago García LI, Martínez Cruz C, Zamudio Lugo I, Rivas Sánchez B, Velasco Castrejón O, Navarrete-Espinosa J. Fatal leptospirosis case in pediatric patient: clinical case. Open J Med Microbiol. 2013;3:12-7.
39. Rivera Flores A, Peña Moctezuma A, Roa Riol MA, Ordoñez Badillo ML. Seroprevalencia del leptospirosis en perros callejeros del norte de la ciudad de México. Vet Mex. 1999;30:105-7.

40. Martínez-Barbosa I, Alpizar-Sosa EA, Gavaldón-Rosas DG, Moles-Cervantes LP, GutiérrezCárdenas MG, García-González $\mathrm{R}$, et al. Canine leptospirosis serology in southern México city. Open J Med Microbiol. 2016;6:171-180

41. Zuerner RL, Cameron CE, Raverty S, Robinson J, Colegrove KM, Norman SA, et al. Geographical dissemination of Leptospira interrogans serovar Pomona during seasonal migration of California sea lions. Vet Microbiol. 2009;137:105-10.

42. Samir A, Soliman R, El-Hariri M, Abdel-Moein K, Hatem ME. Leptospirosis in animals and human contacts in Egypt: broad range surveillance. Rev Soc Bras Med Trop. 2015;48:272-7.

\section{SUPPLEMENTARY MATERIAL}

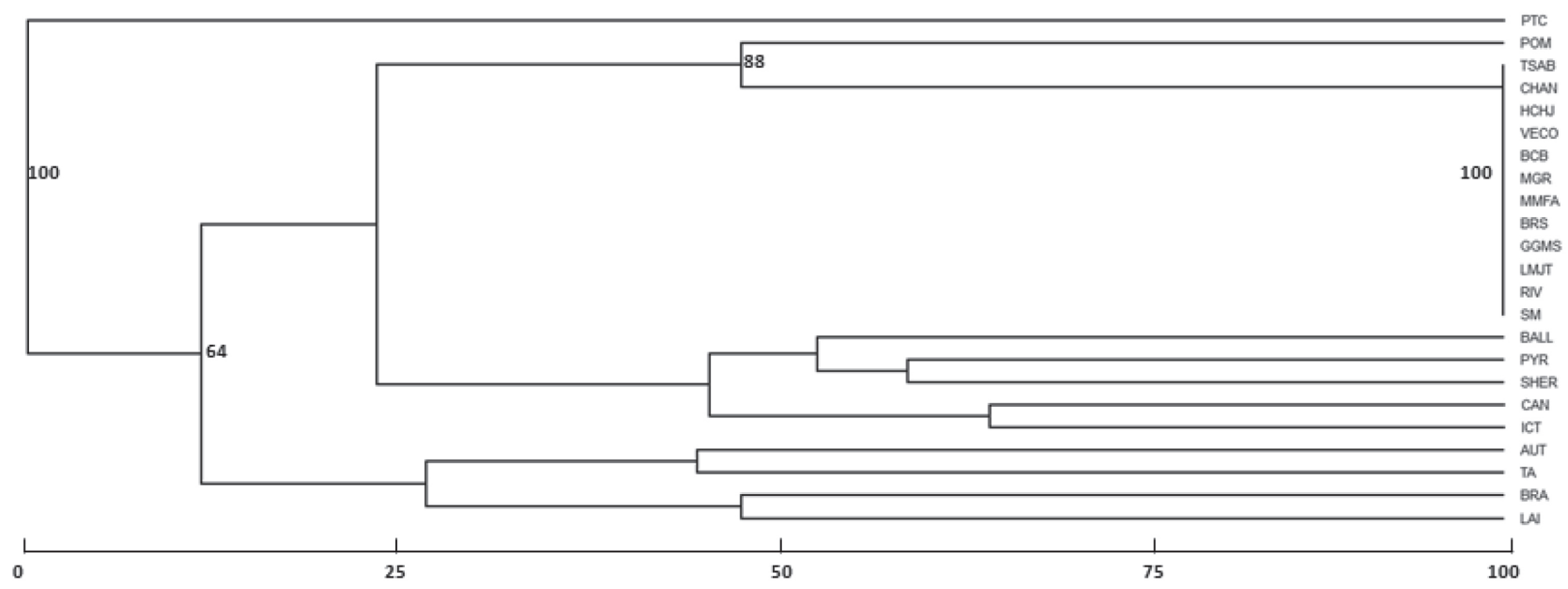

Supplemental Figure - UPGMA dendrogram obtained using the Jaccard's pairwise similarities index from the RAPD profiles generated with primers B11-B12. 